\title{
SISTEM INFORMASI MANAJEMEN ADMINISTRASI DAN KEUANGAN PADA TK-IT PERMATA HATI SUMBERREJO-BOJONEGORO
}

\author{
Salwa Shofia', Dimas Aryo Anggoro² \\ 1,2 Jurusan Teknik Informatika, Fakultas Komunikasi dan Informatika \\ Universitas Muhammadiyah Surakarta \\ Jln. A.Yani Pabelan - Kartasura Kab. Sukoharjo \\ https://www.ums.ac.id/ \\ 1salwashofia31@gmail.com; 2dimas.a.anggoro@ums.ac.id
}

\begin{abstract}
Administrative and financial information systems are one of the most widely applied information technologies to facilitate the management of various data into information. TKIT Permata Hati Sumberrejo still uses manual methods to manage data student, teacher, and staff data as well as recap payment. Data processing is using Microsoft Excel, which results in timeconsuming when entering data and when re-doing data correction before reported. This system was developed aiming to help data and financial management to be more effective and efficient. The information from the data entered can be conveyed properly. Therefore, it is necessary to develop a webbased administrative and financial management information system using PHP programming language with Laravel framework. This system designed using the waterfall method. Then the system will be evaluated using the Black Box and User Acceptance Test. The results of this study are an information system with various features that can be used to manage student, teacher, and staff data, as well as to manage recap payments of tuition fees, POMG, uniforms, and activities. The results of the system testing by the Principal, Treasurer, Administrative, and Admin staff can be concluded that the system is running well and meets the needs of the school..
\end{abstract}

Keywords - Administration, Finance, Laravel, Information System, Waterfall.

Intisari- Sistem informasi administrasi dan keuangan merupakan salah satu teknologi informasi yang banyak diterapkan untuk memepermudah pengelolaan berbagai data menjadi sebuah informasi. Namun pada TK-IT Permata Hati Sumberrejo masih menggunakan metode manual dalam mengolah data siswa, guru dan staff serta data pembayaran berupa pembayaran SPP, POMG, seragam dan kegiatan. Pengolahan data dilakukan menggunakan Microsoft Excel, yang berakibat memakan waktu saat memasukkan data dan saat melakukan koreksi ulang data sebelum dilaporkan pada
Kepala Sekolah. Sistem ini dikembangkan bertujuan agar membantu pengelolaan data dan keuangan agar lebih efektif dan efisien. Sehingga informasi dari data yang dimasukkan dapat tersampaikan dengan baik. Oleh karena itu perlu dikembangkan suatu sistem informasi manajemen administrasi dan keuangan berbasis web menggunakan PHP sebagai bahasa pemrograman dengan framework laravel. Sistem ini dirancang menggunakan metode waterfall dengan enam tahap. Kemudian sistem akan dievaluasi menggunakan Black Box Test dan User Acceptance Test. Hasil dari penelitian ini adalah sebuah sistem informasi dengan berbagai fitur yang dapat digunaan untuk mengelola data siswa, guru dan staff, serta mengelola rekap pembayaran SPP, POMG, Seragam dan kegiatan. Hasil dari pengujian sistem oleh Kepala Sekolah, staff Bendahara, staff Tata Usaha, dan staff Admin dapat ditarik kesimpulan bahwa sistem sudah berjalan dengan baik dan memenuhi kebutuhan dari sekolah.

Kata kunci- Administrasi, Keuangan, Laravel, Sistem Informasi, Waterfall.

\section{PENDAHULUAN}

Segala aspek kepentingan masyarakat saat ini memanfaatkan teknologi informasi yang dapat menyediakan informasi dengan cepat, tepat dan relevan (Kermite, Winarno, \& Rohmani, 2017). Berbagai instansi memanfaatkannya dengan mengembangkan teknologi informasi untuk mengelola sistem informasi manajemen data. Sistem informasi manajemen dijelaskan pada jurnal (Suyitno, 2017) merupakan gabungan dari beberapa sistem yang saling bekerja sama dalam pengolahan data menjadi informasi yang diperlukan dalam pengambilan keputusan selama proses eksekusi sistem manajemen. Salah satu instansi yang menggembangkan sistem informasi manajemen adalah instansi pada lembaga pendidikan. Pada setiap lembaga pendidikan memiliki banyak data dan dokumen penting untuk dikelola. Data tersebut meliputi data pegawai, 
pengajar, siswa, serta keuangan. Pengolahan manajemen keuangan dapat dilakukan setiap saat atau secara periodik, data keuangan tersebut akan mengalami perubahan baik dari pemasukan maupun pengeluaran disetiap bulannya (Nugraha \& Setiawan, 2016). Dengan memanfaatkan teknologi saat ini data-data tersebut dapat diolah menggunakan sistem informasi untuk mengelola administrasi dan manajemen keuangan dalam satu sistem.

Beberapa lembaga pendidikan di Indonesia sudah mulai menggunakan teknologi informasi dalam mengelola administrasi dan memanajemen keuangan. Namun masih banyak lembaga pendidikan yang tertinggal dan masih menggunakan sistem pengelolaan manual. Salah satunya adalah lembaga pendidikan di Taman Kanak-Kanak Islam Terpadu (TK-IT) Permata Hati Sumberrejo ini masih menggunakan metode manual yaitu pembukuan menggunakan Microsoft Excel (Frieyadie, 2015). Sehingga, rawan terjadi redudansi data (Buani, 2017) pada saat melakukan pembukuan, yang mana berakibat memakan waktu untuk melakukan koreksi ulang data sebelum melaporkan kepada kepala sekolah dan yayasan. Selain itu pengelolaan data dan pencarian data saat sedang dibutuhkan akan memakan waktu (Carolina, Ramanda, Rusman, \& Akbar, 2019) dan cukup rumit jika dilakukan secara manual (Sunoto, 2015). Oleh sebab itu dibutuhkan sebuah sistem informasi yang dapat mengelola data administrasi dan manajemen keuangan dalam satu sistem. Pengembangan sistem informasi administrasi dan pengelolaan keuangan ini bertujuan untuk meningkatkan efisiensi dan efektifitas dalam pelayanan dan pengelolaan administrasi pada TK-IT Permata Hati Sumberrejo. Selain itu diharapkan sistem ini dapat memepermudah penyampaian informasi data yang telah diolah kepada pengguna. Sistem ini memiliki beberapa fitur utama yaitu pencatatan, penelusuran dan pencetakan laporan keuangan. Laporan Keuangan sendiri berupa pembayaran Sumbangan Pembinaan Pendidikan (SPP), pembayaran seragam, pembayaran dana Persatuan Orang Tua Murid dan Guru (POMG) serta pembayaran dana kegiatan.

Berdasarkan penelitian yang dilakukan pada sebuah jurnal (Gumawang \& Rakhmadi, 2018) mengenai Pengembangan Sistem Perancangan Manajemen Usaha Kecil Menengah Bidang Kuliner dengan Metode SWOT, pengembangan sistem dilakukan dengan metode waterfall. Metode ini dipilih karena kebutuhan client yang sudah jelas pada awal projek. Pada penelitian jurnal lainnya (Setiawan, Arifin, \& Ardianto, 2018) tentang Implementasi Pengembangan Sistem Media Pembelajaran Pengenalan Komputer: Program
Studi Sistem Informasi Universitas PGRI Madiun juga menggunakan metode pengembangan sistem waterfall. Pada penelitian ini menyatakaan bahwa kelebihan dari model waterfall yaitu mendefinisikan secara utuh kebutuhan sistem pada awal projek serta lebih mudah dalam mengaplikasikannya. Berdasarkan penelitian lain (Habib \& Kindhi, 2018) tentang Rancang Bangun Sistem Informasi Manajemen Keuangan Sekolah. Pengembangan sistem dilakukan menggunakan metode incremental yang memiliki 5 tahapan berupa communication, planning, modelling, construction dan deployment. Pada model pengembangan incremental tidak ada tahapan maintenance yang dikhawatirkan apabila dikemudian hari sistem membutuhkan perbaikan pada program ataupun penambahan fitur. Oleh karena itu sistem manajanemen administrasi dan keuangan ini dirancang menggunakan metode waterfall karena kebutuhan client yang sudah jelas dan tahapan metode yang berurutan serta lebih lengkap.

Sistem informasi manajanemen administrasi dan keuangan pada TK-IT Permata Hati Sumberrejo ini dirancang menggunakan metode waterfall. Pengembangan sistem informasi manajemen administrasi dan keuangan ini bertujuan guna meningkatkan efisiensi dan efektifitas dalam pelayanan dan pengelolaan administrasi pada TK-IT Permata Hati Sumberrejo. Selain itu diharapkan dapat mengurangi terjadinya redudansi data dan memudahkan dalam penelusuran data sebeumnya. Hasil yang diberikan oleh Penelitian Sistem Informasi Manajemen Administrasi dan Keuangan pada TK-IT Permata Hati Sumberrejo ini berupa informasi data diri tenaga pengajar, data diri siswa dan laporan keuangan.

\section{BAHAN DAN METODE}

Pada penelitian ini sistem dikembangkan dengan metode Software Development life Cycle (SDLC). SDLC merupakan metodologi pengembangan sistem untuk merancang, membangun dan memelihara sistem (Alshamrani \& Bahattab, 2015). Metodologi SDLC memiliki beberapa model pengembangan yang disebutkan dalam sebuah jurnal penelitian (Alshamrani \& Bahattab, 2015) diataranya yaitu waterfall, spiral, incremental, $R U P, R A D$ dan beberapa model pengembangan lainnya. Pada pengembangan sistem informasi manajemen administrasi dan keuangan ini dirancang menggunakan model waterfall. Menurut 2 jurnal penelitian yang menyatakan menyatakan bahwa (Gumawang \& Rakhmadi, 2018),(Supriyono, Noviandri, \& Purnomo, 2017) terdapat enam tahapan dalam 
model waterfall yaitu analisis kebutuhan, perancangan, pengembangan, pengujian, implementasi di lingkungan nyata dan perawatan. Metode ini dipilih karena analisis kebutuhan yang sudah jelas pada awal pengembangan dan terdapat tahapan yang beruntut dan lebih lengkap. Metode waterfall pada sistem ditunjukkan pada gambar 1 .

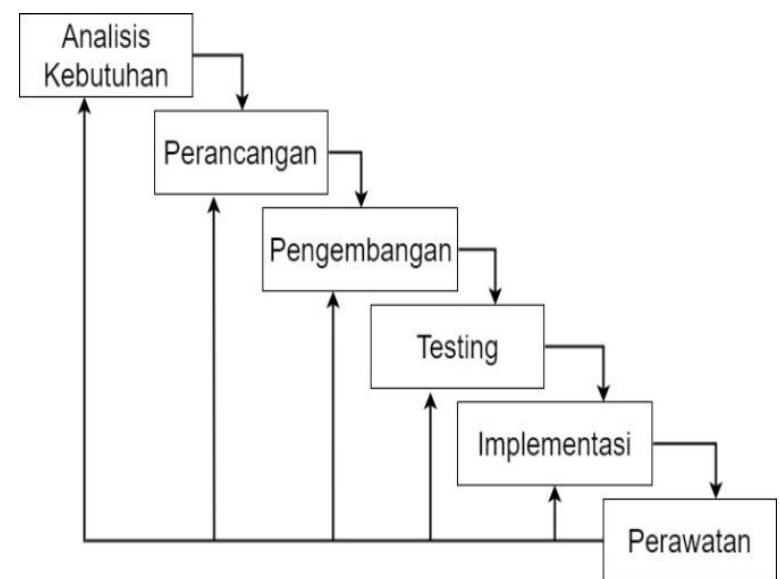

Sumber: (Gumawang \& Rakhmadi, 2018)

Gambar 1. Tahapan Model Waterfall

\section{A. Analisis Kebutuhan}

Pada penelitian ini analisis kebutuhan dilakukan menggunakan metode wawancara dan observasi kepada kepala sekolah, staff tata usaha (TU) dan staff bendahara TK-IT Permata Hati Sumberrejo. Wawancara dan observasi dilakukan untuk mengetahui kebutuhan yang diperlukan dalam pengembangan sistem informasi manajemen administrasi dan keuangan. Sehingga didapatkan informasi dan data yang berguna untuk pengembangan sistem ini. Hasil dari wawancara dan observasi didapati bahwa pada TK-IT Permata Hati Sumberrejo masih menggunakan metode manual pada proses pengarsipan data siswa, guru maupun staff. Selain itu metode yang digunakan dalam pencatatan dan perekapan pembayaran SPP, POMG, seragam dan kegiatan juga masih dilakukan secara manual menggunakan Microsoft Excel. Pihak sekolah juga memberikan contoh data siswa dan rekap pembayaran sebagai acuan dalam pembangunan sistem ini.

\section{B. Perancangan}

Sistem Manajemen Administrasi dan Keuangan ini dirancang menggunakan Unified Modeling Language (UML). Sebuah Jurnal (Maylawati, Darmalaksana, \& Ramdhani, 2018) menyatakan bahwa UML memiliki visualisasi sistem dan dokumentasi yang baik serta merupakan bahasa pemodelan yang populer yang digunakan oleh sejumlah peneliti.

\section{Use Case:}

Use case diagram merupakan bagian dari UML yang menggambarkan serangkaian tindakan yang dapat dijalankan oleh aktor pada sistem (Sousa, Kelvin, Dias Neto, \& Giovanni N. de Carvalho, 2017). Pada gambar 2 menunjukkan use case diagram sistem informasi manajemen administrasi dan keuangan. Diagram ini menggambarkan empat aktor yang memiliki hak akses yang berbeda yaitu, Admin, TU, Bendahara dan Kepala Sekolah. Admin memiliki hak akses untuk mengelola user, seperti menambahkan user name baru kemudian diberikan hak akses sesuai posisi user tersebut. Tata Usaha (TU) memiliki hak akses untuk mengelola dan mencetak seluruh data administrasi siswa, guru dan staff. Bendahara memiliki hak akses untuk mengelola dan mencetak seluruh jenis pembayaran pada sistem ini. Kepala Sekolah hanya memiliki hak akses untuk melihat dan mencetak data siswa, guru dan staff serta rekap pembayaran.

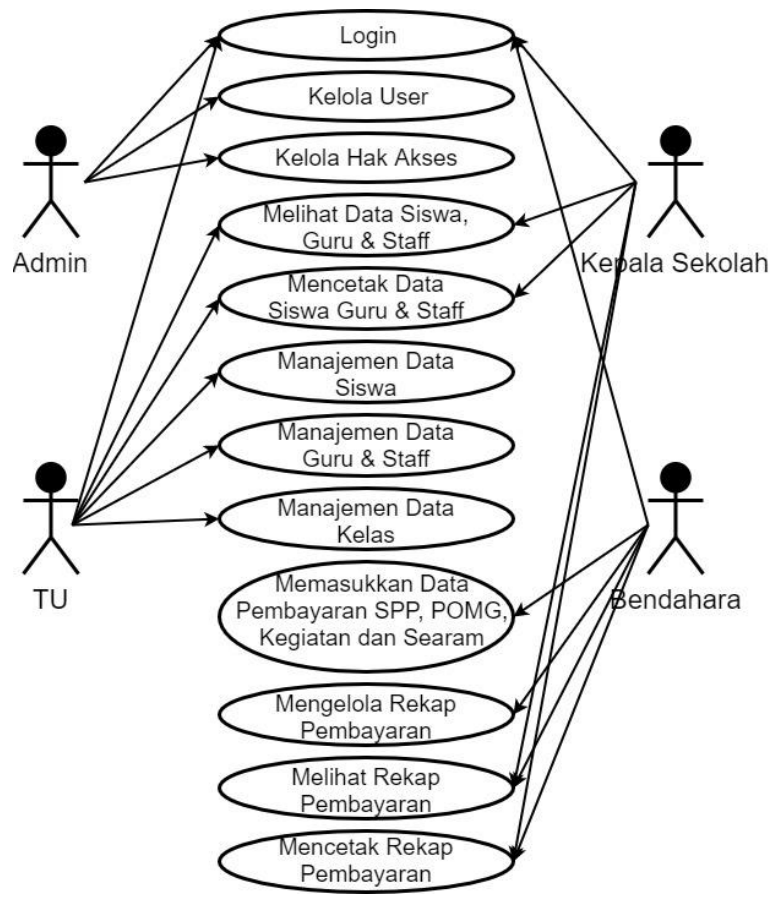

Sumber: (Shofia \& Anggoro, 2020)

Gambar 2. Use Case Diagram

\section{Activity Diagram}

Activity diagaram pada Gambar 3 menggambarkan tentang sistem informasi manajemen administrasi dan keuangan pada TK-IT Permata Hati Sumberrejo dapat dijelaskan sebagai berikut, pada saat aktor berhasil login, aktor akan memiliki beberapa fitur sesuai hak akses yang diberikan. Aktor Tata Usaha (TU) memiliki hak akses penuh ke fitur kelola data berupa kelola daftar siswa, daftar guru dan staff, manajemen 
kelompok kelas, juga fitur cetak data siswa, guru dan staff. Aktor Bendahara memiliki hak akses penuh ke fitur pembayaran aktor dapat melakukan filtering data siswa sesuai tahun masuk dan kelas, kemudian aktor dapat mengelola pembayaran SPP, POMG, Seragam, dan Kegiatan. Kemudian informasi pembayaran siswa tersebut di rekap pada fitur rekap pembayaran. Selain itu Aktor bendahara juga dapat mencetak rekap pembayaran. Aktor Admin memiliki hak akses penuh ke fitur manajemen user dimana aktor dapat melakukan pengelolaan user seperti menambahkan user baru dan diberikan hak akses sesuai kebutuhan user tersebut. Aktor Kepala Sekolah hanya dapat mengakses fitur untuk melihat dan mencetak data siswa, guru dan staff juga laporan rekap pembayaran.

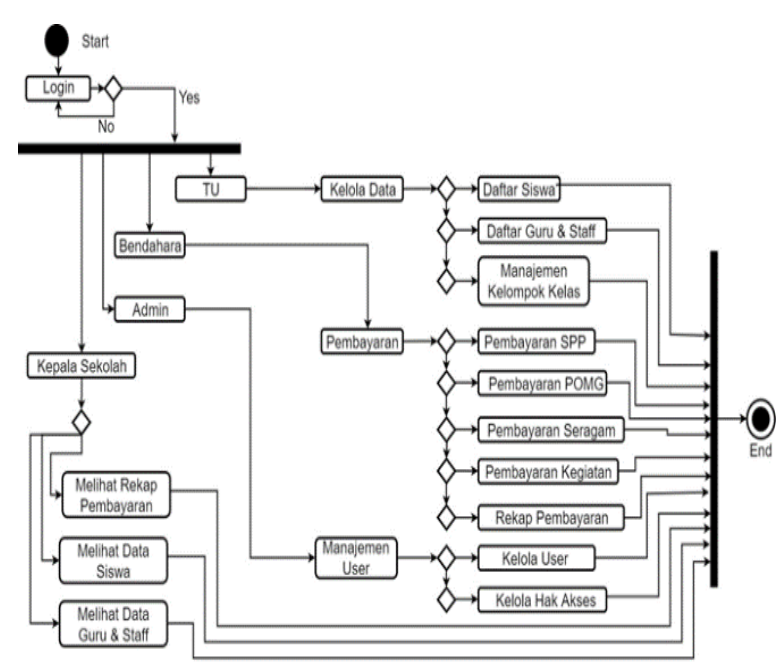

Sumber: (Shofia \& Anggoro, 2020)

Gambar 3. Activity Diagram

\section{Pengembangan}

Sistem Informasi Manajemen Administrasi dan Keuangan pada TK-IT Permata Hati Sumberrejo akan dibangun menggunakan bahasa pemrograman Hypertext Prepocessor (PHP) dengan framework laravel. Laravel merupakan framework yang mudah dipelajari (Benmoussa, Laaziri, Khoulji, Larbi, \& Yamami, 2019), serta memiliki dokumentasi yang cukup lengkap. Laravel menyediakan fungsi berupa penyimpanan kata sandi, keamanan, pengingat password, mengatur ulang password, enkripsi dan validasi data (Parkar, Shinde, Gadade, \& Shinde, 2016). Sedangkan database yang digunakan pada sistem ini adalah MySQL. Database dapat dibuat dengan salah satu aplikasi Open Source yaitu MySQL yang mudah dalam penggunaan, dapat menghubungkan banyak client dalam waktu bersamaan dan terjaminnya faktor keamanannya (Anggoro \& Supriyanti, 2019). Server yang digunakan pada sistem ini adalah Apache yang terdapat pada fitur MySQL.

\section{Database}

Database sistem informasi manajemen administrasi dan keuangan pada TK-IT Permata Hati Sumberrejo ini di rancang menggunakan software DBDesigner. Pada gambar 4 ditampilkan Entity Relationship Diagram. Rancangan database ini di olah menggunakan MySQL.

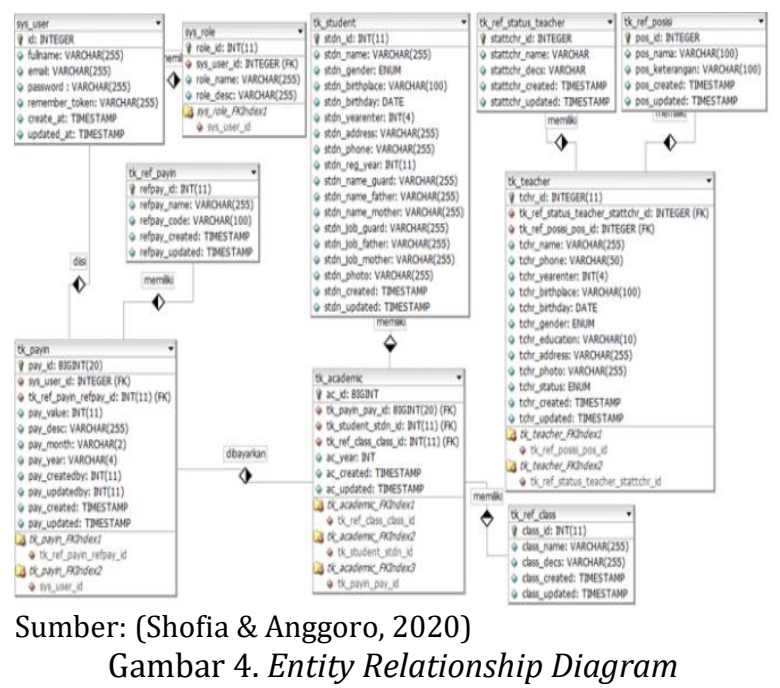

\section{Testing}

Pengujian sistem ini akan dilakukan menggunakan metode Black box dan metode User Acceptance Testing.

\section{Black Box Test}

Metode black box test mengibaratkan sistem sebagai kotak hitam dimana penguji tidak mengetahui internal working dan meguji keberhasilan fungsi pada fitur-fitur yang disediakan oleh sistem. Penguji melakukan test pada aspek-aspek dasar dari sistem (Khan \& Khan, 2012). Salah satu fungsi dari black box adalah melakukan pengujian validitas dari setiap fitur yang ada pada sistem (Mustaqbal, Firdaus, \& Rahmadi, 2015). Aspek yang diujikan berupa fungsi-sungsi dari keseluruhan fitur pengolah data siswa, guru, staff, serta fitur pengolah rekap pembayaran, juga fitur manajemen user.

\section{User Acceptance Test:}

Metode User Acceptance Test merupakan salah satu metode yang digunakan untuk mengukur sistem berjalan sesuai kebutuhan yang diharapkan user pada awal analysis kebutuhan (Maryuliana, Subroto, \& Haviana, 2016). Pengujian ini dilakukan oleh Admin, Kepala Sekolah, Staff TU, dan Bendahara dimana penguji mengoperasikan sistem sesuai hak akses yang diberikan. Setelah 
menjalankan sistem, penguji mengisi kuisioner yang diberikan.

\section{E. Implementasi}

Setelah sistem diuji dan dievaluasi selanjutnya sistem diimplementasikan ke TK-IT Permata Hati Sumberrejo. Sistem digunakan oleh Admin, staff tata usaha, bendahara dan kepala sekolah untuk membantu mengolah dan memanajemen data administrasi siswa, guru dan staff, serta data keuangan berupa pembayaran SPP, POMG, seragam dan kegiatan.

\section{F. Perawatan}

Sistem yang bersih dari kesalahan program akan menjadi sistem yang dapat bekerja dengan maksimal sesuai kebutuhan pengguna. Sehingga tahap perawatan merupakan tahap yang penting dilakukan setelah sistem diimplementasikan pada TK-IT Permata Hati Sumberrejo. Pada tahap ini dilakukan perbaikan atau penambahan fungsi baru yang mendukung sistem berjalan lebih baik kedepannya. Perawatan sistem dilakukan oleh admin yang dilakukan setiap enam bulan sekali atau sesuai kebutuhan client.

\section{HASIL DAN PEMBAHASAN}

Sesuai dengan metode Perancangan waterfall penelitian ini menghasilkan sebuah sistem informasi manajemen data dan keuangan pada TKIT Permata Hati Sumberrejo dengan 4 role user yaitu Tata Usaha, Bendahara, Kepala Sekolah dan Admin. Kemudian untuk pengujian sistem mengunakan pengujian black box dan User Acceptance test.

\section{A. Halaman Login}

Halaman Login digunakan sebagai portal masuk user. User masuk sesuai kebutuhan role yang sudah diberi hak akses. Halaman Login ditunjukkan pada gambar 5 .

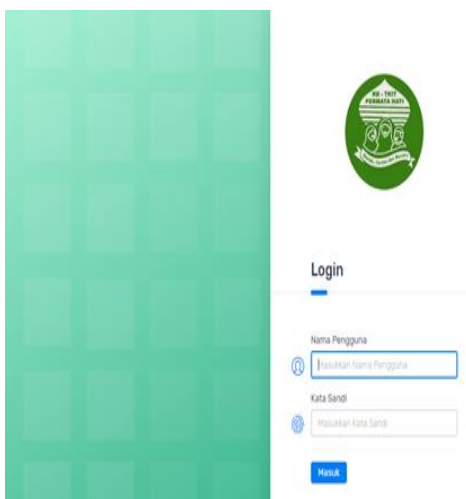

Sumber: (Shofia \& Anggoro, 2020)

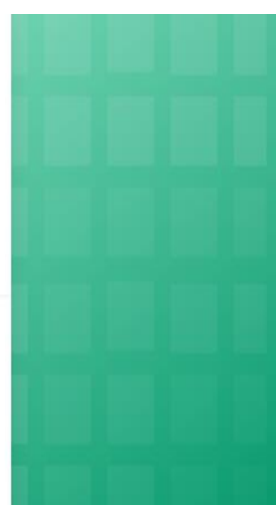

Gambar 5. Halaman Login

\section{B. Halaman Data}

User dengan role Tata Usaha mengarah ke halaman khusus tata usaha, seperti pada gambar 6 . Pada halaman ini terdapat 3 menu utama bagi staff tata usaha yaitu Data Siswa, Data Guru dan Data Kelas. User dapat melakukan pengolahan data administrasi seperti menambah, mengubah, menghapus serta export data pada menu Data Siswa dan menu Data Guru. Sedangkan pada menu Data Kelas, user dapat melakukan pengelompokan siswa sesuai kategori kelas berdasarkan tahun masuk.

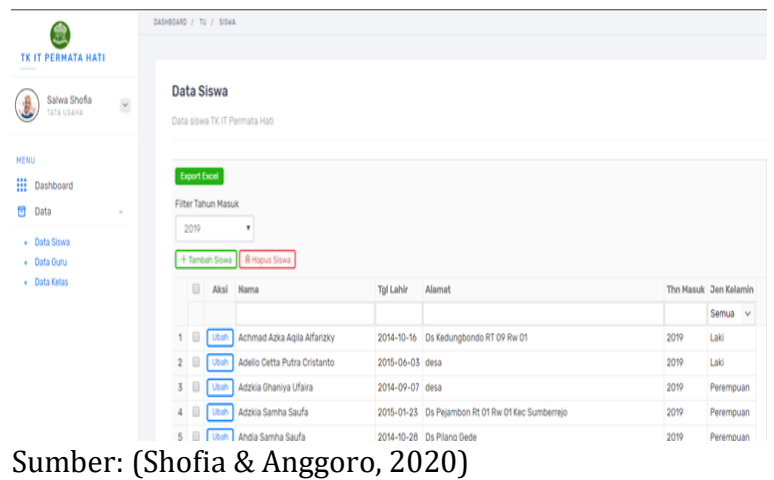

Gambar 6. Halaman Tata Usaha

\section{Halaman Pembayaran}

Halaman Pembayaran dapat diakses oleh user dengan role bendahara, seperti pada gambar 7 . Pada halaman ini terdapat 5 menu utama yaitu menu Pembayaran SPP, Pembayaran POMG, Pembayaran Seragam, Pembayaran Kegiatan serta Rekap Pembayaran. Seluruh menu pembayaran yang telah dipilih tahun ajaran dan kelas menampilkan nama-nama siswa yang sesuai. Kemudian user dapat memasukkan nominal pembayaran, mengubah maupun menghapusnya. Selain itu pada setiap menu pembayaran user dapat melakukan export data. Sedangkan pada menu Rekap Pembayaran seperti pada gambar 8, user dapat memilih fitur rekap bulanan atau rekap tahunan. Pada tiap rekap tertampil total pembayaran pada setiap jenis pembayaran.

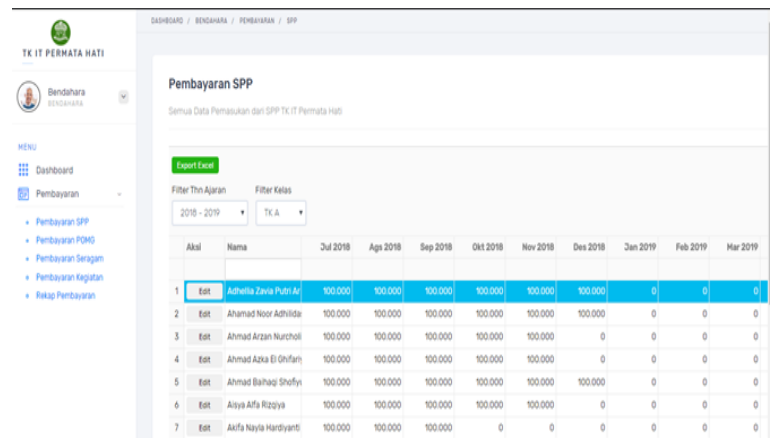

Sumber: (Shofia \& Anggoro, 2020)

Gambar 7. Halaman Pembayaran 


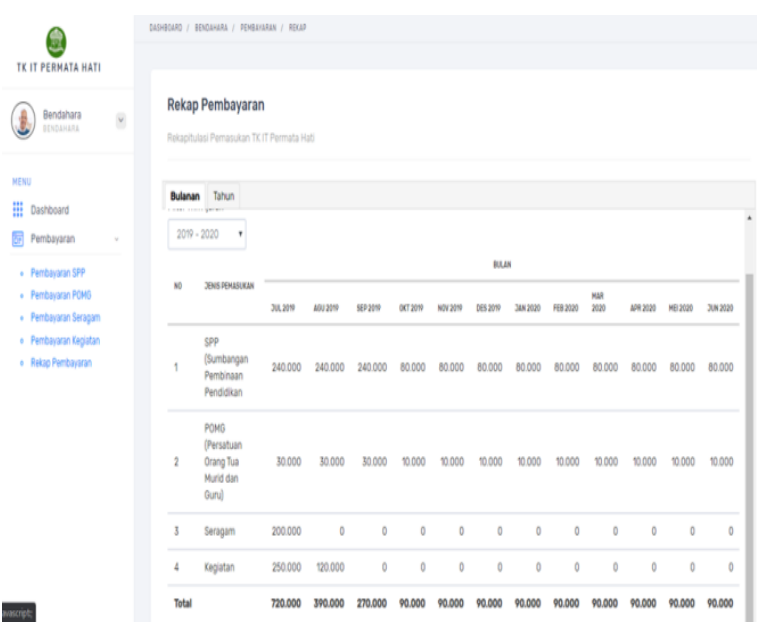

Sumber: (Shofia \& Anggoro, 2020)

Gambar 8. Halaman Rekap Pembayaran

\section{Halaman Rekapitulasi}

Halaman rekapitulasi dapat diakses oleh user dengan role Kepala Sekolah, seperti pada gambar 9. Halaman rekapitulasi memiliki 3 menu utama yaitu menu rekap data siswa, rekap data guru dan rekap pembayaran. Dimana user hanya bisa melihat dan melakukan export pada ketiga menu tersebut.

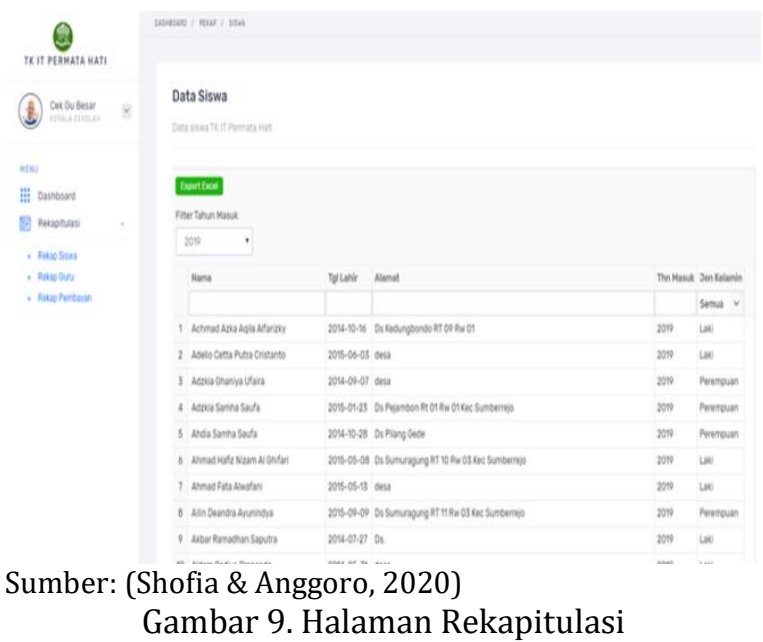

\section{E. Halaman Manajemen User}

Halaman manajemen user dapat diakses oleh user dengan role admin, seperti pada gambar 10 . Terdapat 3 menu utama pada halaman ini, yaitu menu Kelola User, Kelola Menu dan Kelola Hak Akses. Pada menu Kelola User, terdapat fitur untuk menambah, mengubah, memberikan role user dan menghapus user. Sedangkan pada Kelola Menu memiliki fungsi untuk menambah, mengubah dan menghapus menu yang ada pada sistem. Pada menu Kelola Hak Akses terdapat fitur untuk menentukan menu yang dapat diakses tiap role user.

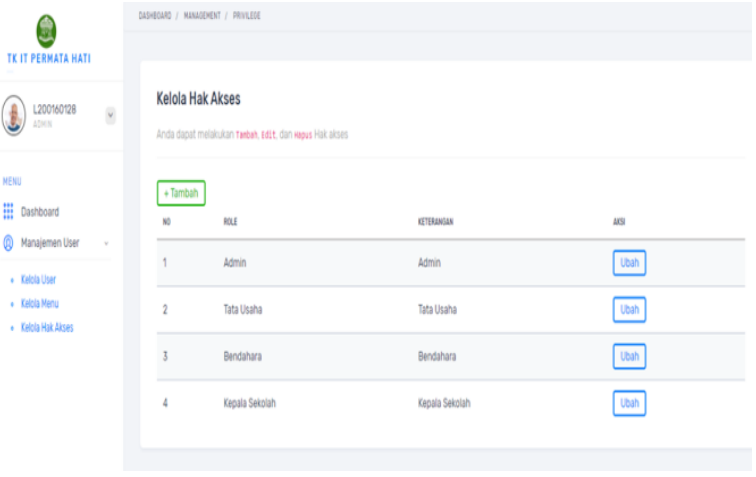

Sumber: (Shofia \& Anggoro, 2020)

Gambar 10. Halaman Manajemen User

\section{F. Testing}

Sistem dilakukan pengujian untuk mengetahui tingkat keberhasilan sistem dalam memenuhi kebutuhan sekolah. Pengujian dilakukan dengan menggunakan black box test dan User Acceptance Test.

\section{Black box Test}

Black box test merupakan tahap pengujian untuk mengetahui sistem berjalan sesuai yang diharapkan atau tidak. Pengujian ini dilakukan oleh seorang validator yang berprofesi sebagai supervisor IT. Metode pengujian black box ini fokus pada bagian hasil eksekusi dari fungsi-fungsi pada sistem. Setiap fungsi pada sistem diuji kesesuaian hasil output-nya. Pada proses pengujian diharapkan dapat ditemukan kesalahan fungsi sistem, sehingga dapat diperbaiki sebelum di berikan pada pengguna. Pengujian black box dapat dilihat pada Tabel 1. Sesuai hasil uji dapat disimpulkan bahwa fungsi-fungsi pada sistem berjalan dengan baik dan memberikan output sesuai harapan.

Tabel 1. Pengujian Black Box

\begin{tabular}{|c|c|c|c|c|}
\hline $\begin{array}{l}\mathrm{N} \\
\mathrm{O}\end{array}$ & $\begin{array}{l}\text { Fungsi } \\
\text { yang diuji }\end{array}$ & Input & Output & $\begin{array}{c}\text { Statu } \\
\mathrm{s}\end{array}$ \\
\hline \multirow{2}{*}{1} & \multirow{2}{*}{$\begin{array}{l}\text { Menu login } \\
\text { masuk } \\
\text { system }\end{array}$} & $\begin{array}{l}\text { Masukkan } \\
\text { username dan } \\
\text { password benar }\end{array}$ & $\begin{array}{l}\text { Menuju } \\
\text { halaman } \\
\text { dashboard }\end{array}$ & Valid \\
\hline & & $\begin{array}{l}\text { Masukkan } \\
\text { username dan } \\
\text { password salah }\end{array}$ & $\begin{array}{l}\text { Kembali ke } \\
\text { halaman } \\
\text { login }\end{array}$ & Valid \\
\hline 2 & $\begin{array}{l}\text { Menu Data } \\
\text { Siswa }\end{array}$ & $\begin{array}{l}\text { Klik data siswa, } \\
\text { melakukan } \\
\text { CRUD. Memfilter } \\
\text { tahun masuk } \\
\text { siswa serta } \\
\text { meng-export } \\
\text { data. }\end{array}$ & $\begin{array}{l}\text { Menampilan } \\
\text { data siswa } \\
\text { sesuai yang } \\
\text { diinputkan, } \\
\text { export data } \\
\text { siswa } \\
\text { berupa file } \\
\text { excel. }\end{array}$ & Valid \\
\hline 3 & $\begin{array}{l}\text { Menu Data } \\
\text { Guru }\end{array}$ & $\begin{array}{l}\text { Klik data guru, } \\
\text { melakukan } \\
\text { CRUD. Memberi } \\
\text { status aktif/non- } \\
\text { aktif serta meng- } \\
\text { export data. }\end{array}$ & $\begin{array}{l}\text { Menampilka } \\
\text { n data guru } \\
\text { sesuai yang } \\
\text { diinputkan, } \\
\text { export data } \\
\text { guru berupa } \\
\text { file excel. } \\
\end{array}$ & Valid \\
\hline
\end{tabular}




\begin{tabular}{|c|c|c|c|c|}
\hline 4 & $\begin{array}{l}\text { Menu Data } \\
\text { Kelas }\end{array}$ & $\begin{array}{l}\text { Meng-generate } \\
\text { data siswa } \\
\text { sesuai kelas dan } \\
\text { tahun ajaran. } \\
\text { Memilih tahun } \\
\text { ajaran dan kelas } \\
\text { siswa. }\end{array}$ & $\begin{array}{l}\text { Menampilka } \\
\text { n data } \\
\text { sesuai hasil } \\
\text { yang } \\
\text { diinputkan. }\end{array}$ & Valid \\
\hline 5 & $\begin{array}{l}\text { Pembayara } \\
\text { n SPP }\end{array}$ & $\begin{array}{l}\text { Memilih tahun } \\
\text { ajaran dan kelas, } \\
\text { klik edit dan } \\
\text { mengisikan } \\
\text { nominal } \\
\text { pembayaran. } \\
\text { Meng-export } \\
\text { data. }\end{array}$ & $\begin{array}{l}\text { Menampilka } \\
\mathrm{n} \text { data } \\
\text { sesuai hasil } \\
\text { input. } \\
\text { Export data } \\
\text { berupa file } \\
\text { excel. }\end{array}$ & Valid \\
\hline 6 & $\begin{array}{l}\text { Pembayara } \\
\text { n POMG }\end{array}$ & $\begin{array}{l}\text { Memilih tahun } \\
\text { ajaran dan kelas, } \\
\text { klik edit dan } \\
\text { mengisikan } \\
\text { nominal } \\
\text { pembayaran. } \\
\text { Meng-export } \\
\text { data. }\end{array}$ & $\begin{array}{l}\text { Menampilka } \\
\mathrm{n} \text { data } \\
\text { sesuai hasil } \\
\text { input. } \\
\text { Export data } \\
\text { berupa file } \\
\text { excel. }\end{array}$ & Valid \\
\hline 7 & $\begin{array}{l}\text { Pembayara } \\
\text { n Seragam }\end{array}$ & $\begin{array}{l}\text { Memilih tahun } \\
\text { ajaran dan kelas, } \\
\text { memasukkan } \\
\text { nomilan } \\
\text { pembayaran dan } \\
\text { menghapus. } \\
\text { Meng-export } \\
\text { data. }\end{array}$ & $\begin{array}{l}\text { Menampilka } \\
\text { n data } \\
\text { sesuai hasil } \\
\text { yang } \\
\text { diinputkan. } \\
\text { Export data } \\
\text { berupa file } \\
\text { excel. }\end{array}$ & Valid \\
\hline 8 & $\begin{array}{l}\text { Pembayara } \\
\text { n Kegiatan }\end{array}$ & $\begin{array}{l}\text { Memilih tahun } \\
\text { ajaran dan kelas, } \\
\text { klik edit dan } \\
\text { mengisikan } \\
\text { nominal } \\
\text { pembayaran. } \\
\text { Meng-export } \\
\text { data. }\end{array}$ & $\begin{array}{l}\text { Menampilka } \\
\mathrm{n} \text { data } \\
\text { sesuai hasil } \\
\text { input. } \\
\text { Export data } \\
\text { berupa file } \\
\text { excel. }\end{array}$ & Valid \\
\hline 9 & $\begin{array}{l}\text { Rekap } \\
\text { Pembayara } \\
\text { n }\end{array}$ & $\begin{array}{l}\text { Memilih menu } \\
\text { rekap } \\
\text { Bulanan/Tahuna } \\
\text { n, memilih tahun } \\
\text { ajaran. Meng- } \\
\text { export data } \\
\text { rekap } \\
\text { pembayaran. }\end{array}$ & $\begin{array}{l}\text { Menampilka } \\
\mathrm{n} \text { data rekap } \\
\text { pembayaran } \\
\text { sesuai hasil } \\
\text { yang } \\
\text { diinputkan. } \\
\text { Export data } \\
\text { berupa file } \\
\text { excel. }\end{array}$ & Valid \\
\hline 10 & Kelola User & $\begin{array}{l}\text { Memilih menu } \\
\text { kelola user, } \\
\text { menambah, } \\
\text { mengubah dan } \\
\text { menghapus data. } \\
\text { Serta melakukan } \\
\text { reset password. }\end{array}$ & $\begin{array}{l}\text { Menampilka } \\
\text { n data user } \\
\text { sesuai hasil } \\
\text { yang } \\
\text { diinputkan. }\end{array}$ & Valid \\
\hline 11 & $\begin{array}{l}\text { Kelola Hak } \\
\text { Akses }\end{array}$ & $\begin{array}{l}\text { Memilih menu } \\
\text { kelola hak akses, } \\
\text { mengubah hak } \\
\text { akses pada jenis } \\
\text { posisi user. }\end{array}$ & $\begin{array}{l}\text { Menampilka } \\
\text { n hak akses } \\
\text { sesuai hasil } \\
\text { yang } \\
\text { diinputkan. }\end{array}$ & Valid \\
\hline 12 & $\begin{array}{l}\text { Rekapitula } \\
\text { si Data } \\
\text { siswa }\end{array}$ & $\begin{array}{l}\text { Memilih menu } \\
\text { data siswa, } \\
\text { memilih tahun } \\
\text { ajaran, export } \\
\text { data siswa. }\end{array}$ & $\begin{array}{l}\text { Menampilka } \\
\text { n data siswa } \\
\text { sesuai } \\
\text { inputan. } \\
\text { Eksport data } \\
\text { berupa } \\
\text { excel. }\end{array}$ & Valid \\
\hline 13 & $\begin{array}{l}\text { Rekapitula } \\
\text { si Data } \\
\text { guru }\end{array}$ & $\begin{array}{l}\text { Memilih menu } \\
\text { data guru, } \\
\text { eksport data } \\
\text { guru. }\end{array}$ & $\begin{array}{l}\text { Menampilka } \\
\text { n data guru, } \\
\text { eksport data } \\
\text { berupa } \\
\text { excel. }\end{array}$ & Valid \\
\hline
\end{tabular}

\begin{tabular}{|c|c|c|c|c|}
\hline 14 & $\begin{array}{l}\text { Rekapitula } \\
\text { si } \\
\text { Pembayara } \\
\text { n }\end{array}$ & $\begin{array}{l}\text { Memilih menu } \\
\text { rekap } \\
\text { pembayaran, } \\
\text { memilih tahun } \\
\text { ajaran, eksport } \\
\text { rekap } \\
\text { pembayaran } \\
\text { bulanan/tahuna }\end{array}$ & $\begin{array}{l}\text { Menampilka } \\
\text { n rekap } \\
\text { pembayaran } \\
\text { sesuai tahun } \\
\text { yang dipilih. } \\
\text { Eksport data } \\
\text { berupa } \\
\text { excel. }\end{array}$ & Valid \\
\hline
\end{tabular}

Sumber: (Shofia \& Anggoro, 2020)

\section{User Acceptance Test}

User Acceptance Test (UAT) merupakan tahap pengujian sistem oleh pengguna. Pengguna menilai sistem sesuai kuisioner yang diberikan. Penilaian bertujuan untuk mengetahui tingkat kelayakan sistem bagi pengguna. Pada kuisioner terdapat pertanyaan yang diajukan berkaitan dengan sistem yang dapat dilihat pada Tabel 2. Pertanyaan tersebut diajukan pada 4 responden guna mengetahui tingkat kepuasan pengguna pada sistem.

Tabel 2. Pertanyaan yang diajukan dalam UAT

\begin{tabular}{cl}
\hline $\begin{array}{c}\text { Kode } \\
\text { Soal }\end{array}$ & \multicolumn{1}{c}{ Pertanyaan } \\
\hline p1 & $\begin{array}{l}\text { Bagaimana tingkat kecepatan dalam mengakses } \\
\text { sistem ini? }\end{array}$ \\
\hline p2 & Bagaimana tampilan sistem ini ? \\
\hline p3 & $\begin{array}{l}\text { Bagaimana fungsi menu-menu pada setiap fitur } \\
\text { ? }\end{array}$ \\
\hline p4 & $\begin{array}{l}\text { Bagaimana menurut anda penyampaian } \\
\text { informasi pada sistem ini ? }\end{array}$ \\
\hline p5 & $\begin{array}{l}\text { Apakah sistem sudah memenuhi kebutuhan } \\
\text { sekolah? }\end{array}$ \\
\hline p6 & $\begin{array}{l}\text { Apakah sistem ini mempermudah pengelolaan } \\
\text { administrasi ? }\end{array}$ \\
\hline
\end{tabular}

Sumber: (Shofia \& Anggoro, 2020)

Setelah dilakukan pengujian pada pengguna, hasil dari kuisioner akan dihitung. Perhitungan dilakukan sesuai indikator dan poin nilai yang terpadat di Tabel 3. Hasil perhitungan dapat dilihat pada Tabel 4. Perhitungan dilakukan dengan acuan rumus dari referensi (Rahmatulloh, Rachman, \& Anwar, 2019) dapat dilihat di persamaan (1) berikut ini.

$$
Y=\left(\frac{\text { Jjawaban } \times \text { nilai }}{\sum \text { responden } \times 5}\right) \times 100 \%
$$

Tabel 3. Indikator dan nilai perhitungan

\begin{tabular}{cccc}
\hline Nilai & Keterangan & Bobot & Prosentase \\
\hline A & $\begin{array}{c}\text { Sangat: } \\
\text { Mudah/Bagus/Sesuai/Jelas }\end{array}$ & 5 & $81 \%-100 \%$ \\
\hline B & Mudah/Bagus/Sesuai/Jelas & 4 & $61 \%-80 \%$ \\
\hline C & Netral & 3 & $41 \%-60 \%$ \\
\hline D & $\begin{array}{c}\text { Cukup: } \\
\text { Sulit/Bagus/Sesuai/Jelas }\end{array}$ & 2 & $21 \%-40 \%$ \\
\hline E & $\begin{array}{c}\text { Sangat : Sulit/Jelek/Tidak } \\
\text { Sesuai/Tidak Jelas }\end{array}$ & 1 & $0 \%-20 \%$ \\
\hline
\end{tabular}

Sumber: (Rahmatulloh et al., 2019) 
Tabel 4. Hasil Perhitungan UAT

\begin{tabular}{|c|c|c|c|c|c|c|c|c|c|c|c|c|}
\hline \multirow{2}{*}{ 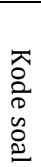 } & \multicolumn{6}{|c|}{ Jawaban } & \multicolumn{4}{|c|}{ Nilai } & \multirow{2}{*}{ 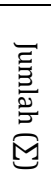 } & \multirow[b]{2}{*}{$\mathrm{Y}$} \\
\hline & A & B & C & D & $\mathrm{E}$ & $\begin{array}{l}\vec{x} \\
\text { v }\end{array}$ & $\underset{x}{\ddot{x}}$ & $\underset{w}{\tilde{x}}$ & $\underset{x}{\forall}$ & $\stackrel{\sqrt[[1]{x}}{\stackrel{\bullet}{\bullet}}$ & & \\
\hline $\begin{array}{l}\mathrm{p} \\
1\end{array}$ & 2 & 1 & 1 & 0 & 0 & • & 4 & 3 & 0 & 0 & $\begin{array}{l}1 \\
7\end{array}$ & $\begin{array}{l}85 \\
\%\end{array}$ \\
\hline $\begin{array}{l}\mathrm{p} \\
2\end{array}$ & 1 & 3 & 0 & 0 & 0 & $G$ & $\begin{array}{l}1 \\
2\end{array}$ & 0 & 0 & 0 & $\begin{array}{l}1 \\
7\end{array}$ & $\begin{array}{l}85 \\
\%\end{array}$ \\
\hline $\begin{array}{l}\mathrm{p} \\
3\end{array}$ & 2 & 2 & 0 & 0 & 0 & $\overrightarrow{0}$ & 8 & 0 & 0 & 0 & $\begin{array}{l}1 \\
8\end{array}$ & $\begin{array}{l}90 \\
\%\end{array}$ \\
\hline $\begin{array}{l}\mathrm{p} \\
4\end{array}$ & 2 & 1 & 1 & 0 & 0 & • & 4 & 3 & 0 & 0 & $\begin{array}{l}1 \\
7\end{array}$ & $\begin{array}{l}85 \\
\%\end{array}$ \\
\hline $\begin{array}{l}\mathrm{p} \\
5\end{array}$ & 3 & 1 & 0 & 0 & 0 & $\vec{v}$ & 4 & 0 & 0 & 0 & $\begin{array}{l}1 \\
9\end{array}$ & $\begin{array}{l}95 \\
\%\end{array}$ \\
\hline $\begin{array}{l}\mathrm{p} \\
6\end{array}$ & 2 & 2 & 0 & 0 & 0 & • & 8 & 0 & 0 & 0 & $\begin{array}{l}1 \\
8\end{array}$ & $\begin{array}{l}90 \\
\%\end{array}$ \\
\hline
\end{tabular}

Sumber: (Shofia \& Anggoro, 2020)

Pada pertanyaan $\mathrm{p} 1$ menghasilkan prosentase nilai $85 \%$ yang termasuk dalam kategori nilai $\mathrm{A}$. Pertanyaan p2 menghasilkan prosentase nilai $85 \%$ yang termasuk dalam kategori nilai A. Pertanyaan p3 menghasilkan prosentase nilai 90\% yang termasuk dalam kategori nilai A. Pertanyaan $\mathrm{p} 4$ menghasilkan prosentase nilai $85 \%$ yang termasuk dalam kategori nilai A. Pertanyaan p5 menghasilkan prosentase nilai 95\% yang termasuk dalam kategori nilai A. Pertanyaan p6 menghasilkan prosentase nilai $90 \%$ yang termasuk dalam kategori nilai A Kemudian pada perhitungan pertanyaan kedua menghasilkan prosentase nilai Hasil dari perhitungan keseluruhan adalah $\sum \mathrm{Y}=$ $88,67 \%$ mendekati indikator skala terbaik. Menurut penelitian dari jurnal (Rahmatulloh et al., 2019) prosentasi $88,67 \%$ sudah termasuk dalam kategori sangat setuju. Sehingga sistem manajemen administrasi dan keuangan ini dapat diterima dengan baik oleh pihak TK IT Permata Hati Sumberrejo.

\section{KESIMPULAN}

Setelah dilakukan pengujian sistem pada pengguna, dapat ditarik kesimpulan bahwa sistem dapat mempermudah pihak sekolah dalam pengelolaan data siswa, guru, staff, maupun keuangan. Sistem ini dapat membantu pihak sekolah dalam melakukan perekapan pembayaran siswa secara cepat dan tepat. Sehingga mempermudah proses administrasi pada sekolah dan informasi tersampaikan kepada pengguna secara baik. Sistem informasi manajemen administrasi dan keuangan ini berjalan sesuai dengan harapan dan dapat memenuhi kebutuhan sekolah. Adapun saran dari penulis yang dapat dipertimbangkan untuk mengembangkan sistem ini yaitu membuat sistem informasi manajemen administrasi dan keuangan berbasis mobile android/iOS. Agar user interface yang ditampilkan pada mobile lebih user friendly saat digunakan.

\section{REFERENSI}

Alshamrani, A., \& Bahattab, A. (2015). A Comparison Between Three SDLC Models Waterfall Model, Spiral Model, and Incremental/Iterative Model. IJCSI International Journal of Computer Science Issues, 12(1), 106-111.

Anggoro, D. A., \& Supriyanti, W. (2019). Aplikasi Sistem Pendukung Keputusan dengan Metode AHP untuk Pemilihan Siswa Berprestasi di SMAN Kebakkramat. Jurnal Penelitian Dan Pengabdian Kepada Masyarakat UNSIQ, 6(3), 163-171. https://doi.org/10.32699/ppkm.v6i3.777

Benmoussa, K., Laaziri, M., Khoulji, S., Larbi, K. M., \& Yamami, A. El. (2019). A new model for the selection of web development frameworks: application to PHP frameworks. International Journal of Electrical and Computer Engineering (IJECE), 9(1), 695. https://doi.org/10.11591/ijece.v9i1.pp695703

Buani, D. C. P. (2017). PERANCANGAN SISTEM INFORMASI KOPERASI SIMPAN PINJAM STUDI KASUS: KOPERASI SMK 18 LPPM RI SIDAREJA CILACAP | JITK (Jurnal Ilmu Pengetahuan dan Teknologi Komputer). JITK (Jurnal Ilmu Pengetahuan Dan Teknologi Komputer), 3(1), 133-138. Retrieved from http://ejournal.nusamandiri.ac.id/index.php /jitk/article/view/371

Carolina, I., Ramanda, K., Rusman, A., \& Akbar, I. (2019). RANCANG BANGUN APLIKASI STOCK OPNAME PADA PT. ARIE MUTI BERBASIS ANDROID. INTI Nusa Mandiri, 14(1), 1-6. https://doi.org/10.33480/INTI.V14I1.544

Frieyadie, F. (2015). PEMBANGUNAN SISTEM INFORMASI INVENTORY MENGGUNAKAN LINEAR SEQUENTIAL MODEL UNTUK PENINGKATAN LAYANAN INVENTORY BARANG. Jurnal Techno Nusa Mandiri, 12(2), 209-114.

https://doi.org/10.33480/TECHNO.V12I2.45 1

Gumawang, A. K. A., \& Rakhmadi, A. (2018). 
Pengembangan Sistem Perancangan Manajemen Usaha Kecil Menengah Bidang Kuliner dengan Metode Swot. In Proceeding of The 7th University Research Colloquium 2018: Bidang Teknik dan Rekayasa (pp. 159170). Surakarta: Muhammadiyah Surakarta. Retrieved

from http://repository.urecol.org/index.php/proc eeding/article/view/30

Habib, A., \& Kindhi, B. Al. (2018). Rancang Bangun Sistem Informasi Manajemen Keuangan Sekolah. INTENSIF: Jurnal Ilmiah Penelitian Dan Penerapan Teknologi Sistem Informasi, 2(2), https://doi.org/10.29407/intensif.v2i2.1213 9

Kermite, R. Y., Winarno, A., \& Rohmani, A. (2017). Perancangan Sistem Administrasi Sekolah dengan SMS Gateway Berbasis Web Menggunakan Gammu pada SMK LPI Semarang. JOINS (Journal of Information System), 2(1), 15-27. Retrieved from http://publikasi.dinus.ac.id/index.php/joins /article/view/1459

Khan, M. E., \& Khan, F. (2012). A Comparative Study of White Box, Black Box and Grey Box Testing Techniques. International Journal of Advanced Computer Science and Applications, $3(6)$, 12-15. https://doi.org/10.14569/ijacsa.2012.03060 3

Maryuliana, Subroto, I. M. I., \& Haviana, S. F. C. (2016). Sistem Informasi Angket Pengukuran Skala Kebutuhan Materi Pembelajaran Tambahan Sebagai Pendukung Pengambilan Keputusan Di Sekolah Menengah Atas Menggunakan Skala Likert. Jurnal Transistor Elektro Dan Informatika (TRANSISTOR EI), 1(2), 1-12. Retrieved from http://jurnal.unissula.ac.id/index.php/EI/art icle/view/829

Maylawati, D. S., Darmalaksana, W., \& Ramdhani, M. A. (2018). Systematic Design of Expert System Using Unified Modelling Language. IOP Conference Series: Materials Science and Engineering, 288(1). https://doi.org/10.1088/1757899X/288/1/012047

Mustaqbal, M. S., Firdaus, R. F., \& Rahmadi, H. (2015). PENGUJIAN APLIKASI MENGGUNAKAN BLACK BOX TESTING BOUNDARY VALUE ANALYSIS (Studi Kasus :
Aplikasi Prediksi Kelulusan SNMPTN). Jurnal Ilmiah Teknologi Informasi Terapan (JITTER), I(3), 31-36.

Nugraha, S. A., \& Setiawan, R. (2016). PERANCANGAN SISTEM INFORMASI PENGOLAHAN ADMINISTRASI KEUANGAN SEKOLAH MENENGAH PERTAMA ISLAM TERPADU ASSALAM GARUT. Jurnal Algoritma Sekolah Tinggi Teknologi Garut, 13(1), 320-332.

Parkar, V. V, Shinde, P. P., Gadade, S. C., \& Shinde, P. M. (2016). Utilization of Laravel Framework for Development of Web Based Recruitment Tool. National Conference On "Changing Technology and Rural Development," 36-41.

Rahmatulloh, A., Rachman, A. N., \& Anwar, F. (2019). Implementasi Web Push Notification Pada Sistem Informasi Manajemen Arsip Menggunakan PUSHJS. Jurnal Teknologi Informasi Dan Ilmu Komputer (JTIIK), 6(3). https://doi.org/10.25126/jtiik.20196936

Setiawan, D., Arifin, I., \& Ardianto, R. (2018). Implementasi Pengembangan Sistem Media Pembelajaran Pengenalan Komputer: Program Studi Sistem Informasi Universitas PGRI Madiun. INTENSIF Jurnal Ilmiah Penelitian Teknologi Dan Penerapan Sistem Informasi, 2(2), 127-135.

Shofia, S., \& Anggoro, D. A. (2020). Laporan Akhir Penelitian Mandiri: Sistem Infomasi Manajemen Administrasi dan Rekap Keuangan pada TK-IT Permata Hati Sumberrejo. Surakarta.

Sousa, T. C. de, Kelvin, L., Dias Neto, C., \& Giovanni N. de Carvalho, C. (2017). A Formal Semantics for Use Case Diagram Via Event-B. Journal of Software, 12(4), 189-200. https://doi.org/10.17706/jsw.12.3.189-200

Sunoto, I. (2015). PERANCANGAN SISTEM INFORMASI ADMINISTRASI AKADEMIK BERBASIS WEB. TEKNIK FTUP, Faktor Exacta, 5(2), 146-155. Retrieved from http://journal.lppmunindra.ac.id/index.php/ Faktor_Exacta/article/view/189

Supriyono, H., Noviandri, A. M., \& Purnomo, Y. E. (2017). Penerapan Sistem Informasi Berbasis Komputer Untuk Pengelolaan Aset Bagi SMP Muhammadiyah 1 Kartasura. The 6th University Research Colloquium 2017, 59-70. 
Suyitno. (2017). ANALISIS PENERAPAN SISTEM INFORMASI MANAJEMEN DAN KOMPETENSI PEGAWAI SERTA PENGARUHNYA TERHADAP KINERJA PEGAWAI. Journal of Business Administration, 1(2), 270-279. 